\title{
視野画像列を利用した経路表現に基づくナビゲーション
}

\author{
松 本 吉 央* 稲 葉 雅 幸* 井上 博 允* $^{*}$
}

\section{Visual Navigation Based on View-Sequenced Route Representation}

\author{
Yoshio Matsumoto*, Masayuki Inaba* and Hirochika Inoue*
}

\begin{abstract}
Previous work in vision-based mobile robot has been lacking models of the route which can be utilized for recognition of (1) position identification, (2) steering direction determination, and (3) obstacle detection, simultaneously. In this paper, we propose a new visual representation of the route, the "View-Sequenced Route Representation (VSRR)." A VSRR is a non-metrical model of the route, which contains a sequence of front view images along a route memorized in the recording run. In the autonomous navigation, the three types of recognition described above are achieved in real-time by matching between the current view image and the memorized view sequence using correlation technique. We also developed an easy procedure for acquiring VSRRs, and a quick control procedure using VSRRs. The VSRR is especially useful for representing routes in the corridors. Experimental results of autonomous navigation using a two-wheeled robot in a real corridor are presented.
\end{abstract}

Key Words: Navigation, Real-time Vision, Memory-based Approach, Image Sequence, Block Matching

\section{1.はじめに}

これまで, 移動ロボットの誘導法として, 画像を学習するこ とで生成されたデータを経路モデルとする研究が行われてき た. Pomerleau [1], Meng [2] らは, 走行路の画像をニューラ ルネットに入力して画像と制御量の関係を，また，Crespi [3] らはメモリベースドアプローチにより画像と走行路の中心線か らの位置・姿勢の関係を学習させた。これらの学習により, 画 像によるロバストな誘導が実現されたが、「走行路に沿う」ため の進行方向の制御を行っているにとどまっており，複雑な経路 の走行では, 経路上の位置の認識を行うための別の手法が必要 であるという久点があった。

そこで近年, 視覚情報をより直接的に記憶し, 蓄えられた記 憶を用いて位置の認識を行う手法が研究されてきた。この場合, まずはじめに画像を記憶するための記録走行を行って経路表現 を生成したあとで, その経路表現に含まれる画像と現在の画像 の比較・対応付け（マッチング）を行うことで位置の認識を行 う. 画像を直接記憶する手法は, 記憶する情報量を増やすこと で認識アルゴリズムを単純化し，ロバストに行うことを目指し ているが, 画像デー夕は一般に非常に情報量が多いため, その まま大量のシーンを記憶することは難しく，またシーンのマッ チングの計算コストも大きい.そこで, (1) どの方向の画像を,

原稿受付 1995 年 11 月 28 日

*東京大学工学系研究科

*Graduate School of Engineering, The University of Tokyo
（2）どのように情報量を圧縮して記憶し，(3) どのようなマッ チングを行うか, という点が問題となる.

Zheng [4] らは経路の横方向の連続画像を用いた経路モデル を提案し，画像の縦エッジや色分布のマッチングを用いて自律 走行時の経路上の自己位置の認識を行った。また，前田ら [5] は全方位の画像をフーリエ変換して記憶した環境モデルを提案 し，フーリエ係数の比較による画像マッチングにより効率良く 現在のロボットの位置および姿勢の認識を行った．また，黒須 ら [6] は進行方向正面の画像を，VTR を用いることで画像を大 量に記憶したものを経路表現として用いることを提案し，画像 中の縦線のマッチングを行い, ロボットの位置・姿勢の認識を 行った.

これらの画像の記憶を用いる手法に共通した特徵として, 環 境モデルの生成が容易である点が挙げられる。これまでに数多 く研究されてきた移動ロボットにおける超音波距離センサや画 像のエッジなどを用いる環境認識手法では, 環境の幾何形状を モデルとして与える（文献 [7] など）ためその作製に手間がか かるが，画像を直接モデルとして用いる場合にはその必要がな いためである．

しかし，これらはいずれも実際の走行に用いられるまでには 至っていない，移動ロボットの環境認識として，自己位置，進 行方向, 障害物の有無の 3 点を知ることは不可欠であるが，い ずれの経路モデルでもこれらすべてを行うための情報を持って いなかったためであると考えられる.

本論文では，走行時に見える進行方向の視野全体の画像の列 
（視野画像列）を記憶することによる視覚移動ロボットに適し た経路モデル（視野画像列経路表現）を提案し，これを用いた ロボットの誘導法について述べる。この手法では, 記憶した画 像列と走行時に見える画像の比較により環境認識を行い,

・明るさなど, 環境の見え方が時間によって大きく変化し ない

-カメラの視野に, ある程度近くまでの走行環境（床, 壁な ど）が映っている

という条件を満たす建物内などの環境において，

- 経路上の自己位置, 進行方向および障害物を認識できる

・実時間で走行制御を行うことができる

- 1 回の記録走行により容易に経路教示が行える

という特徴がある。

以下, 次章では, 視野画像を用いた走行経路モデルの生成に ついて述べる，次に視野画像のマッチングを用いた自己位置の 同定, 進行方向の決定, 障害物の検出の三つの環境認識手法に ついて説明し, 続いてその結果に基づき行動制御を行う手法に ついて述べる，次に実際の廊下環境において行った実験結果を 示し, 最後に考察および今後の課題を述べる.

\section{2. 視野画像列経路表現}

Horswill [8] は低解像度の CCD から直接画像を得て, 単純 な画像処理により整備された建物内の床面の抽出を行って走行 するロボットを開発したが, この研究のなかで自己位置の認識 のために, 粗いシーン全体の画像を用いたマッチング手法を用 いている。これは，あらかじめ環境内の認識するべき場所で記 憶した画像と, 現在得られる画像がマッチするならば, 記憶し たときと同じ場所にいると判断するものである. 特定のランド マークを敷設したり画像から抽出するという処理の必要性がな くなるという利点があるため, 実環境に応用しやすいが, 廊下 のように似たシーンが頻繁に現れる環境では，ある画像が複数 のシーンでマッチしてしまう可能性があり，このままでは特徴 的な小数のシーンの認識にしか使えない.

本研究で提案する視野画像列経路表現は, 連続的にシーン を記憶するところがこれと異なる．本研究での処理の概要を Fig. 1 に示す.まず記録走行に扔いて覚えたい経路を実際に走 行し, 進行方向を向いたカメラから得られる視野画像および画 像間の関係を記憶して視野画像列経路表現を生成する。自律走 行時には, 記憶した画像列とその場で見える画像を比較するこ とにより, 画像列中の自己位置, 進む方向, 障害物の有無を認 識し行動を行う.

\section{1 視野画像の生成}

本手法では, 走行経路において進行方向を向いたカメラから 得られる画像を記憶やマッチングに用いるのであるが，カメラ から得られる画像をそのまま大量に記憶することは難しい。移 動ロボットは, 重さや電力容量などの点から, 搭載できるハー ドウエアが制限されるからである。また, 黒須ら [6]は画像の 記憶に VTR を用いているが，データにランダムアクセスでき ない点が問題となる.

そこで本研究ではカメラから得られる画像 (512[pixel] $\times$ $512[$ pixel $] \times 8[$ bit $])$ を縮小 $(32[$ pixel $] \times 32[$ pixel $] \times 8[$ bit $])$
(1) Teaching Run

Memorizing views along the route

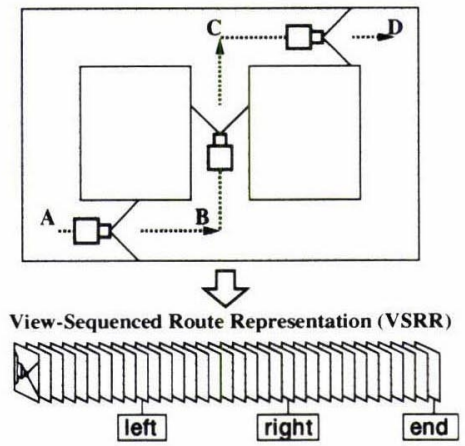

(2) Autonomous Navigation

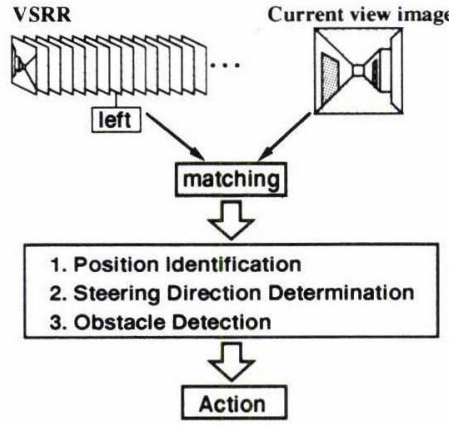

Fig. 1 Outline of navigation using View-Sequenced Route Representation

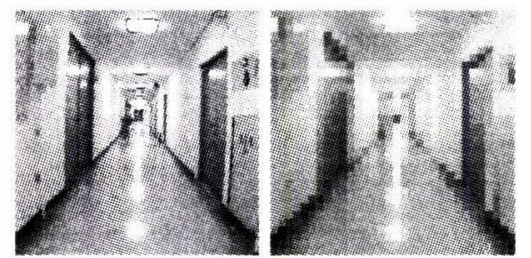

Fig. 2 Raw Image from camera (left) and generated View Image

して用いる(Fig. 2).この画像を視野画像 $I$ と呼ぶ．画像サイ ズの縮小には, 間引きでなく平滑化（平均・縮小処理）を用い る。これは, ある領域に含まれる画素の輝度值の平均をとり, それをその領域を代表する画素の輝度值とする処理である。こ れにより，デー夕量を大幅に削減すると同時に画像のノイズを 低減し，また高速な画像間のマッチング処理が可能となる.

\section{2 視野画像列経路表現の生成}

視野画像 $I$ を経路に沿って順番に並べて記憶した画像列を視 野画像列 $\left\{M_{i} \mid 0 \leq i<N\right\}$ と呼ぶ. 視野画像列を得るために は, 記録走行を行う必要がある.記録走行での視野画像列の記 憶は, 移動経路を直線経路に分割し, 各直線経路において, 以 下の手順により行う.

（1）現在の視野画像を記憶し $M_{i}$ とする.

(2) 現在の視野画像 $I_{t}$ が， $M_{i}$ からある程度変化するまで口 ボットを前進させる。

(3) $i=i+1$.

(4) (1) に戻る. 
「視野画像が変化した」かどうかは次章で述べる画像間の マッチングにより判断する．つまり，直前に記憶した視野画像 と現在の視野画像のマッチングを行い，その差がいき值を越え たら新たな視野画像を記憶する。この手法で記憶して行くと， 等間隔の距離を進むごとに記憶するのではなく, シーンの複雑 さや変化の多さによって自動的に記憶の頻度を変化させること になる．いき值は，屋内での実験でおよそ $0.5 〜 1[\mathrm{~m}]$ 間隔で画 像を記憶するように設定した。

視野画像列だけでは，画像間の関係が示されていないため， どのように行動を行えば次の画像に進めるのか分からず，経路 表現としては不十分である．そこで，画像 1 枚ごとに次の画像 との関係の情報 $T_{i}$ を付加して記憶する．例えば直線経路上の 画像には Forward，右に曲がる角の画像には Right，ゴール の画像には End というタグをつける．このタグは，記録時走 行に人間がロボットに与えるものである.

このように生成した $\left\{M_{i}\right\}$ と $\left\{T_{i}\right\}$ を合わせて視野画像列経 路表現と呼ぶ.

\section{3. 視野画像列経路表現を用いた環境認識}

\section{1 自己位置の同定}

一般に, 移動ロボットの自己位置の同定は

（1）移動ロボット自身の概略位置がすでに分かっている場合に, より正確な位置を確認したい場合（局所的位置の同定）

（2）移動ロボット自身の位置が不明な場合に，地図上での位置 を知りたい場合（大域的位置の同定）

の二つに大別できるが、ここでは（1）を視野画像列経路表現 の記憶に基づき行う手法について述べる.

\section{1 .1 視野画像のマッチング手法}

記境した視野画像と現在の視野画像など，2枚の視野画像を 比較しそれらがどのくらい似ているかを計算する処理を，視野 画像のマッチングと呼ぶ．これは視野画像の中心部の縋長の領 域をテンプレートとしたブロックマッチング（Fig.3）で，画 像圧縮用 LSI を搭載した画像処理ボード [9] を用いて $4.3[\mathrm{~ms}]$ で行うことができる．マッチングの結果として，画像の水平方 向のずれ量 $u$,およびエラー值 err (ブロック間誤差, この値 が小さいほど相関が高い）が得られる。

テンプレートのサイズは縦 25 [pixel]，横 16 [pixel] とした． テンプレートが縦長であるのは，画像のずれが横方向には（口 ボットの回転や並進により) 大きくなる可能性があるのに対し て，縦方向には（ロボットの移動が平面上であるので）ほとん ど発生せず，探索範囲が縦方向には小さくてよいからである． こうしてシーンの特徴をたくさん含んだ大きなテンプレートを 用いることで，障害物の出現等の環境の局所的な変化に影響さ れにくい，安定したマッチングを行うことができる．

\section{1 .2 視野画像列中のマッチング範囲}

Fig. 4 に, $0.9[\mathrm{~m}]$ 離れた地点 A, B において記憶した 2 枚の 視野画像 $M_{A}, M_{B}$ と, その近傍の地点における視野画像 $I_{x}$ と のマッチングを行った実験結果を示す．A 地点付近では視野画 像 $I_{x}$ は $M_{A}$ と相関が高いが, 地点 Bへ近づくに従ってその相 関は徐々に低くなり, 逆に $I_{x}$ と $M_{B}$ の相関が高くなっている ことが分かる。この性質を用いることで，カメラが地点 $\mathrm{A}, \mathrm{B}$

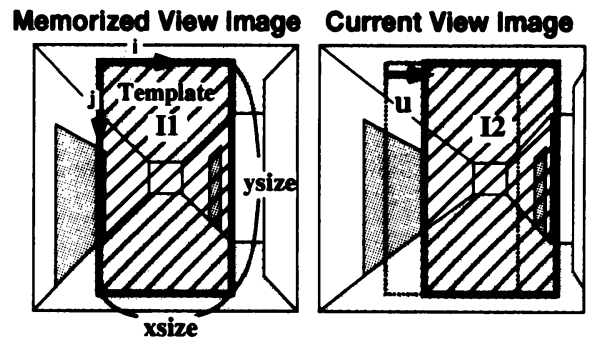

err $=\sum_{i=0}^{x s i z e-1} \sum_{j=0}^{y s i z e-1}\left|11_{i, j}-12_{i, j}\right| \quad(x s i z e=16$, ysize=25)

Fig. 3 Matching method between two view images
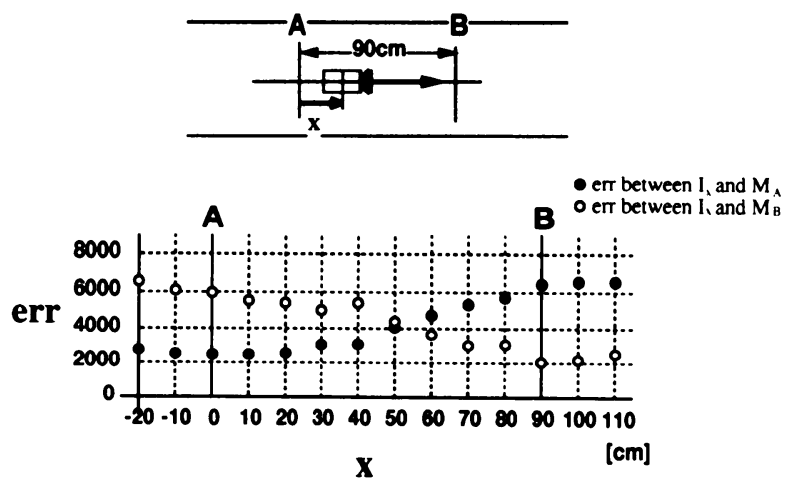

Fig.4 Experimental result of matching as a function of longitudinal translation of the camera

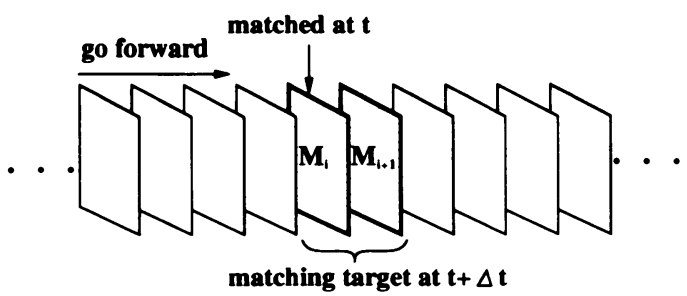

Fig. 5 Matching target in the view sequence

の近傍にあることが分かっている場合には，そのどちらにより 近いかを判別することができる．

画像列中の自己位置の同定は，このような局所的なマッチン グのエラー值の比較によって行う．ロボットが前進している場 合, 時刻 $t-\Delta t$ に得られた視野画像 $I_{t-\Delta t}$ が記憶した視野画 像 $M_{i}$ とマッチしているとすると, 画像の変化は連続的である ので, 視野画像 $I_{t}$ は $M_{i}, M_{i+1}$ のどちらかとマッチするはず である.そこでこの 2 枚の視野画像と時刻 $t$ に得られる視野画 像の間でマッチングを行い（Fig.5)，その結果エラー値の低い 方を時刻 $t$ でマッチした視野画像，つまり現在の画像列中での 自己位置とする。

Fig. 6 は，ロボットを直進させたときに得られる画像と，記 憶しておいた画像列とのマッチングの変化の様子を示してい る. 図中の err3 は記憶した 3 枚目の画像とのマッチングのエ ラー值の遷移を示す曲線である . err3 は画像を記憶した位置 $(1.8[\mathrm{~m}])$ 付近で極小值をとり，ここではロボットの画像列中 の位置は 3 枚目である．ロボットの前進を続けると err3 は徐々 


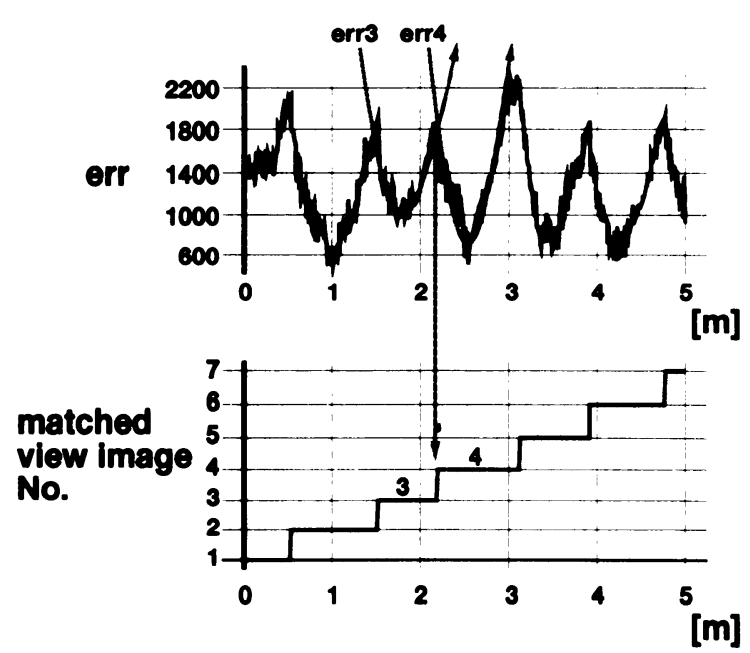

Fig. 6 Experimental result of position identification in the view sequence based on matching error

に増加して $2[\mathrm{~m}]$ を過ぎた地点で err4 を越える。ここでロボッ トの位置は 4 枚目に切り替わる。このような遷移を続けること で，ロボットは画像列中の自己位置を同定していく．この図か ら分かるように，平滑化された視野画像を用いたマッチングの 結果は自己位置を求めるのに十分安定している。

\section{2 進行方向の決定}

本手法では, 記憶した視野画像と現在の視野画像のずれを求 め, どちらに進めば記憶した画像の見え方に近づくかという定 性的な性質を用いてモータへビジュアルフィードバックをかけ る。ここでは，廊下環境（幅 $2.5[\mathrm{~m}]$ ）においてカメラ（画角 $\left.56^{\circ}\right)$ の位置, 姿勢のずれが, 画像のマッチング結果にどのよ うな影響を及ほすかを調べた実験結果について述べる。

\section{2 .1 位置姿勢のずれの検出}

カメラの初期位置を廊下の中心に置き廊下の長手方向を向け たところとする.

Fig.7 は, カメラが回転したときの, 画像の水平方向のずれ およびエラー值の変化の様子を示している．横軸ははじめに視 野画像を記憶した方向からの回転角度, 緃軸はマッチングの結 果から得られた画像の水平方向の位置のずれ（単位は視野画像 の [pixel]. 1 [pixel] は視野角では約 $1.5^{\circ}$ に対応) である。この ように, マッチングによりカメラの回転により発生する視野画 像のずれが検出できる. $15^{\circ}$ 以上回転するとテンプレートが視 野からはみ出してしまうため, マッチングが失敗し, 正しい結 果が得られていない。 これは, エラー值の増大から判別できる。

次に Fig. 8 に, カメラの位置が横方向に移動したときの, 画 像の水平方向のずれおよびェラー値の変化の様子を示す. 横軸 は廊下の長手方向とは直角な方向ではじめに視野画像を記憶し た地点からの移動距離である. 縦軸はマッチングの結果から得 られた画像の位置のずれおよびエラー值の変化である.この図 から, カメラが原点から離れるに従って画像の見え方が変化す るために画像間のエラ一值が増大するが, 画像のずれは検出で きていることが分かる。

画像中に非常に遠方の物体しか写っていない場合には, カメ ラの並進による画像の変化はほとんど起こらないが, 廊下のよ
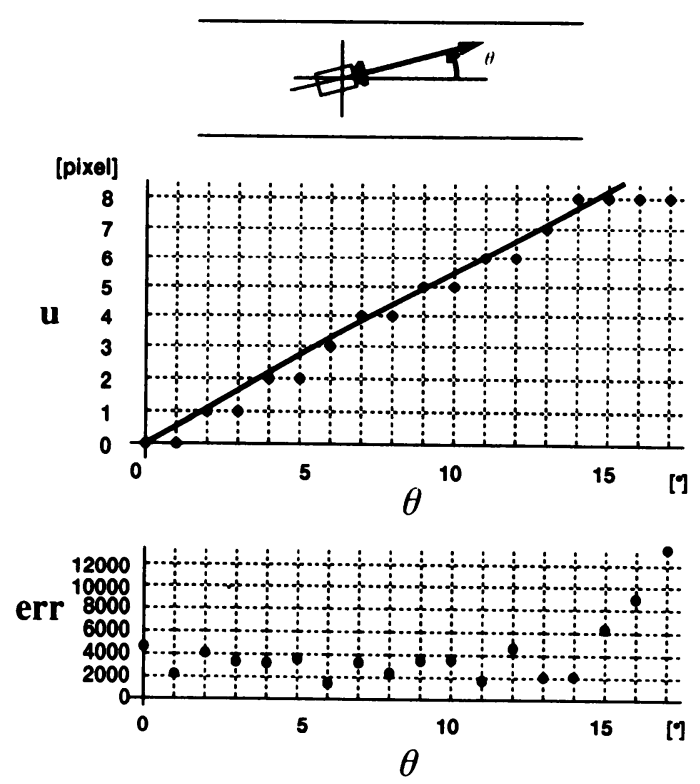

Fig. 7 Experimental result of matching as a function of rotation of the camera
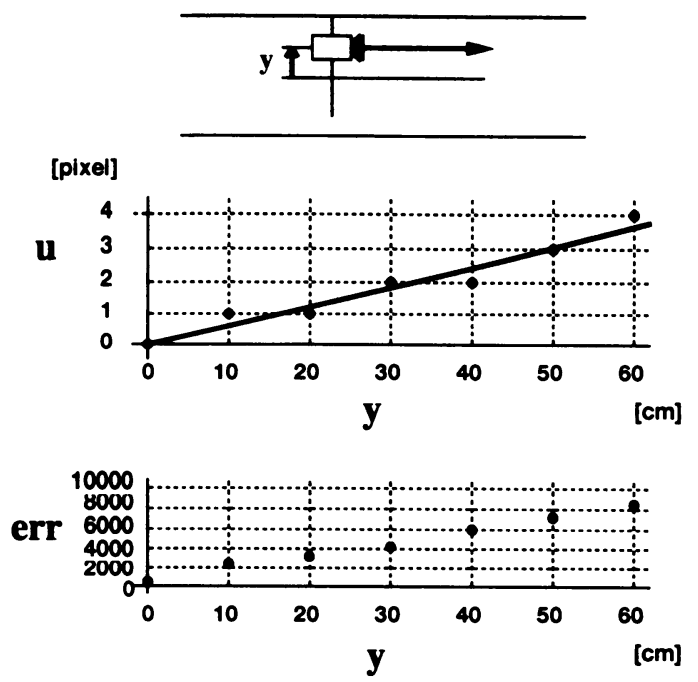

Fig. 8 Experimental result of matching as a function of lateral translation of the camera

うに画像中にある程度近くのもの（床や壁）まで写っている場 合には，このように画像のマッチング結果からカメラの姿勢だ けでなく位置のずれも検出できる．ただし，この単一のテンプ レートのマッチングの結果からは, カメラの位置と姿勢を同時 に決定することはできない.

\section{2 .2 進行方向の決定}

本手法の視野画像のマッチングの結果からは, カメラの位置 と姿勢を同時に決定することはできない．そこで, どちらに進 めば記憶した見え方に近づくかという定性的な性質を用いて モータへビジュアルフィードバックをかける。

Fig.9に, マッチングの結果, 画像が右にずれていたときの 走行路に対するカメラの位置姿勢の例を示す。いずれの場合も， カメラは右前方に進むことで画像のずれが少なくなることが分 


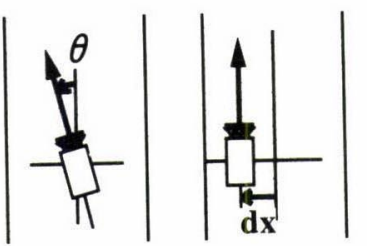

Fig.9 Examples of camera position when memorized view image matched in the right side
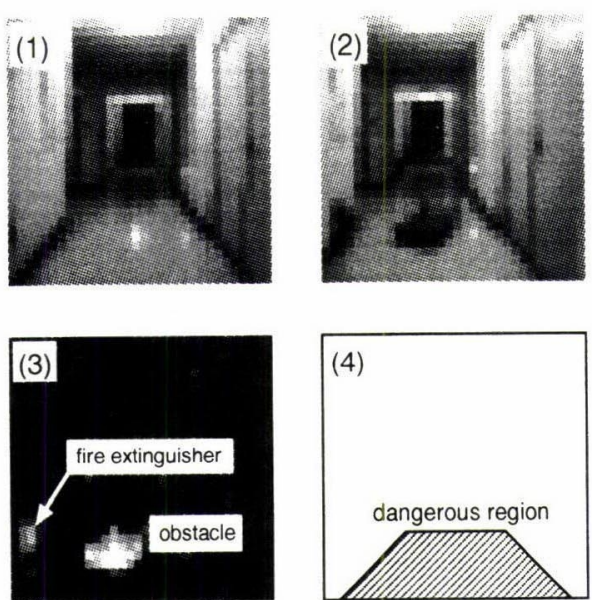

Fig. 10 Result of obstacle detection. (1) memorized view image, (2) current view image, (3) detected obstacles, and (4) dangerous region

かる.この際の操舵角 $\theta$ (正面右向き正) は, gain を定数, $u$ を画像の水平方向のずれ量として,

$$
\theta=\operatorname{gain} \times u
$$

という式によって表現される.なお gain の値は実験的に適当 なものを求めて用いた。この操蛇角は 2 輪独立駆動の移動口 ボットでは左右の車輪のスピードの差に変換されて制御が行わ れる。

\section{3 障害物の検出}

走行路にある障害物の検出は, 記憶した視野画像と現在の視 野画像の差分を利用して行う。まず現在マッチしている視野画 像を、マッチングの結果のずれの分だけ並行移動する，次にそ の画像と現在の視野画像の差分画像を生成し, 変化した領域を 抽出する．記録走行時の環境には何も置かれていないというこ とが仮定されていれば,この変化領域は新たに置かれた障害物 であるとみなすことができる（Fig.10）。

このようにして検出された障害物が，危険領域（ロボットの 進行方向の走行路）にあるかどうかを調べることで，危険領域 に障害物を検出した場合だけ停止し，壁に沿って置かれた消火 器などを検出しても走行を続けることができる.

\section{4. 視野画像列経路表現を用いた行動制御}

視野画像列経路表現を利用した基本動作として

- 直進（画像の方向に進む）

・コーナーリング (その場で画像の方向を向く) typedef struct

2: \{

3: int err;

4: int $\mathrm{u}$;

5: \} MatchingResult;

7: typedef char ViewImage [32*32];

8: MatchingResult result, result2;

9: Viewimage $\mathrm{M}[\mathrm{N}], \mathrm{I}$;

10: int $\mathrm{T}[\mathrm{N}]$;

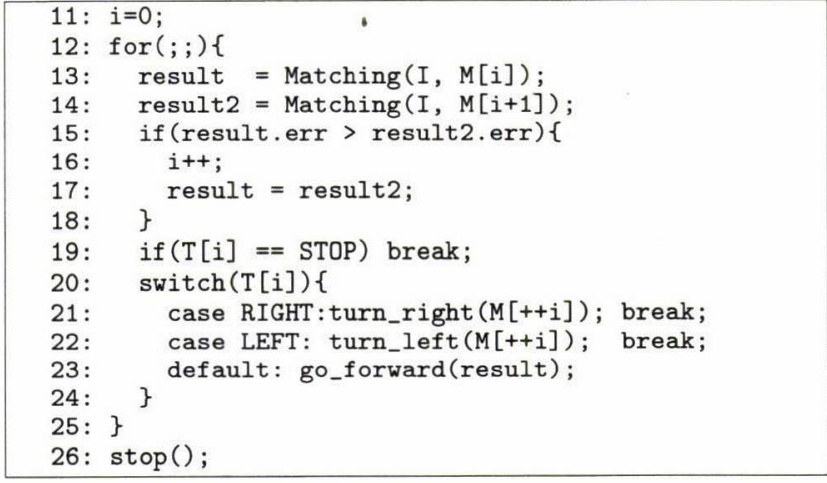

Fig. 11 Processing of VSRR

を用意し，この二つの動作の繰り返しにより，建物内の移動を 行う。視野画像列経路表現から行動を決定するアルゴリズムを

Fig. 11 に示す.

\section{1 直進}

ロボットが直進している場合, 画像列中での局所的自己位置 の同定を行い，この最もマッチした記憶画像とのエラー值がい き值よりも小さければマッチングが成功していると判断する. そのマッチングの結果から進行方向を決定し, 走行を行う。こ のとき，走行スピードは一定とする．

また障害物を危険領域に検出した場合や，そもそもマッチン グが失敗していると判断した場合は停止する。障害物が消え， マッチングが再び成功するようになった場合には，走行を再開 する。

\section{2 コーナーリング}

コーナーリングは, 曲がった先に見える 1 枚の視野画像のみ を用いて行う (Fig. 12).(1) まず，カメラのパンを曲がろうと している方向に向け, そのときに得られる視野画像と記憶した 視野画像のマッチングをとり，記憶した視野画像が曲がろうと している方向にあることを確認する.（2）次に，カメラが常に 曲がろうとしている方向を向くよう，マッチングの結果をパン 角にフィードバックさせながら，ロボット本体をその場で回転 させる.(3) カメラとロボット本体の相対角度が 0 になれば, コーナーリングの終了である.

\section{5. 走 行 実 験}

\section{1 実験システム}

実験に用いた移動ロボットシステム（Fig. 13）は，屋内用の 電動車椅子（（株）ユニカム MOUSE MS-2）をコンピュータ からコントロールできるように改造したものである. 左右の車 輪を独立に駆動してその場で旋回することが可能で, 


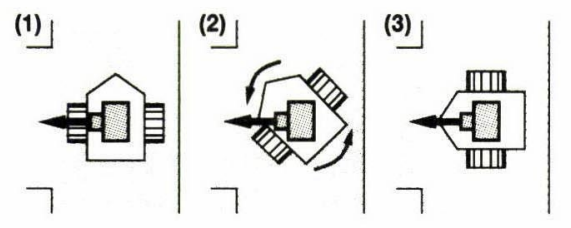

Fig. 12 Cornering action sequence

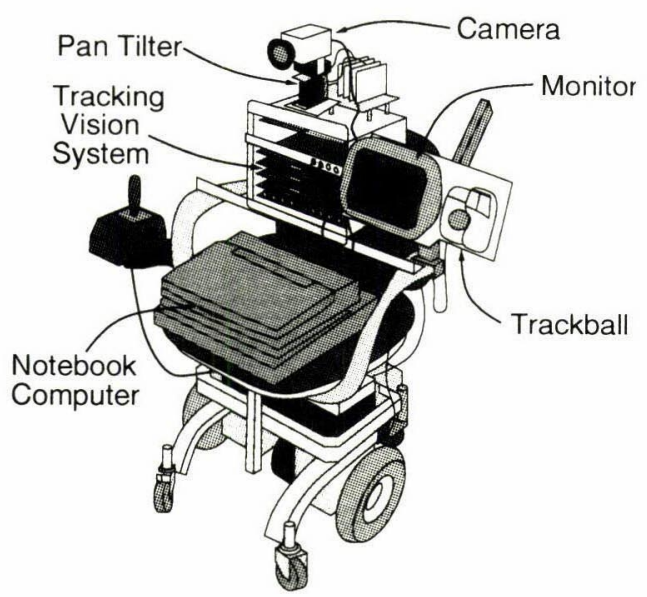

Fig.13 Robot System Overview

・視覚処理ボード

・ビデオカメラ +パンチルター

・トラックボール

・液晶ディスプレイ

をとりつけてある。

\section{2 廊下走行実験}

東京大学工学部 9 号館において, 研究室の前から出発して, 左折, 右折, 左折を繰り返してエレベータの前まで移動する合 計 $35[\mathrm{~m}]$ の経路（Fig. 15）を自律走行させる実験を行った.

5.2 .1 経路教示

視野画像による走行経路の教示は,できるだけ走行環境には 余計な物/人などがない状態で行う。これは, 教示時に記憶し た視野画像を基準に走行時の環境認識を行うためである。常に 置かれているものであれば, それごと記憶させて構わない.

経路は, 直線とコーナーリングに分割して教示する. 直線に おいては人間がロボットを経路に沿って移動させ, その間に自 動的に画像を記憶させる。また，コーナーリングを行う地点ま で行ったら, トラックボールを用いて画面上に表示されている メニューにより右/左折を選ぶ. 次にロボットをその場で曲が る方向へ回転させ, もう一度トラックボールのボタンを押すま では, 新たな視野画像の記憶は行わない, また, 経路の終点ま で来たときはメニューで終了を選択する，このように，視覚の みを用いて極めて容易な操作により経路の教示を行うことがで きた.こうして記憶した 50 枚の視野画像列の一部を Fig. 14 に 示す.

\section{2 .2 自律走行}

自律走行時の様子を Fig. 15 に示す。ロボットは $0.3[\mathrm{~m} / \mathrm{s}]$ 程 度の速度で走行を行った. 走行中にロボットの遠い前方を人が 歩いていても, 視野画像のなかでは遠くに小さくしか映らない
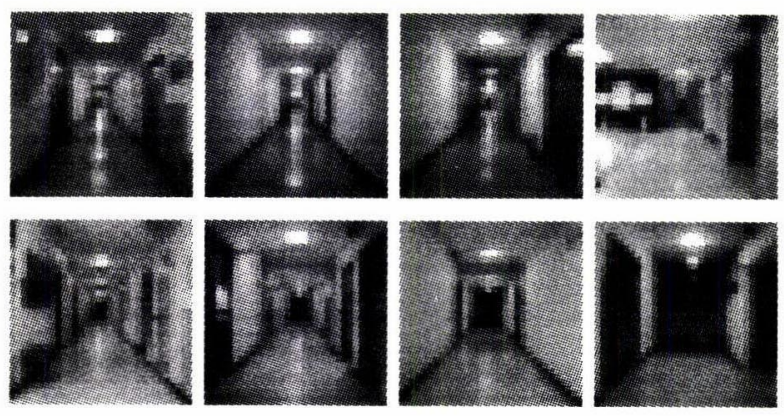

Fig. 14 Samples of memorized views images in the route shown in Fig. 15

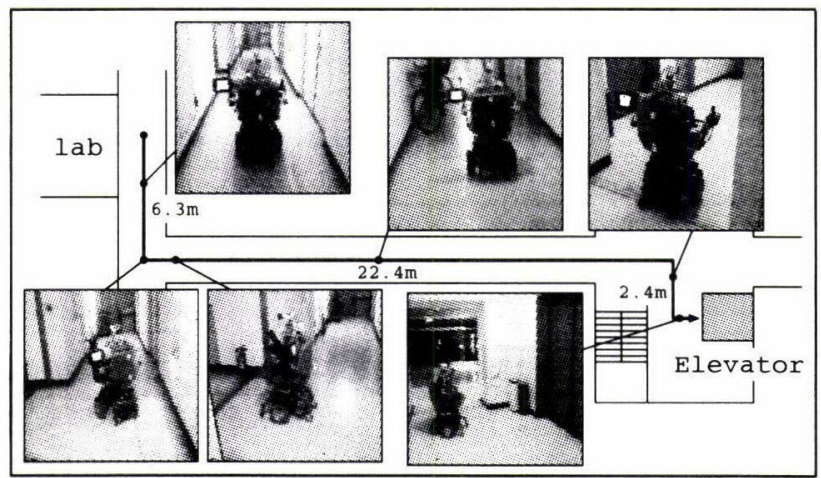

Fig. 15 Experimental environment

ために影響を受けずに走行を続け，危険な領域まで近づくと停 止することができた。

\section{3 考察}

本研究で用いたマッチング手法では，ロボットの位置と姿勢 を同時に決定することはできないため, 記憶している画像の方 向に「向かう」という単純な制御により直進している.ここで は, この制御手法の妥当性を判断するため, (1) 自律走行の正 確さ，(2) 必要な教示の正確さ，(3) 初期位置のずれへの対応, の 3 点について考察する。

\section{3 .1 自律走行の正確さ}

自律走行実験での直線部分での走行軌跡を Fig. 16 に示す. $y=0$ が教示しようとした目標経路である. 同一の教示デー 夕を用いて 4 回自律走行を行った結果得られた軌跡は, 最大 でも目標経路から䛊差 $\pm 8[\mathrm{~cm}]$ であり, 我々が許容範囲と考え る $\pm 10[\mathrm{~cm}]$ の誤差に収まっている.また各軌道のばらつきは $\pm 6[\mathrm{~cm}]$ 程度である。これらの誤差の原因として, (1) 初期姿 勢のずれ，(2) 教示の不正確さ（特に画像を記憶する瞬間の姿 勢のずれ),(3) 画像のノイズ,(4) 環境の変化, (5) 制御の時間 遅れ, など様々なものが考えられるが, この図からはそれらの 合計としての誤差は実用上問題ない範囲であると言える.

\section{3 .2 必要な教示の正確さ}

本実験での経路教示は人間がロボットを押すことで行うが, 本実験のロボットは 2 輪独立駆動の機構を持つため, クラッチ を外した状態では直進性は低く, 正確な教示を行うのは困難で ある.この教示の不正確さの影響は, 各軌跡において常に同じ ように摇れている部分（Fig. 16 での 5〜6 [m] の部分など）に 


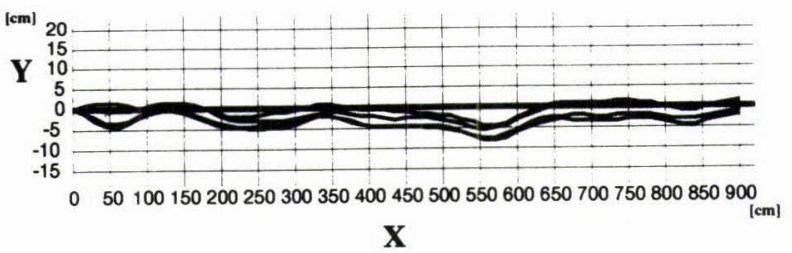

Fig.16 Trajectries of autonomous navigation (1)

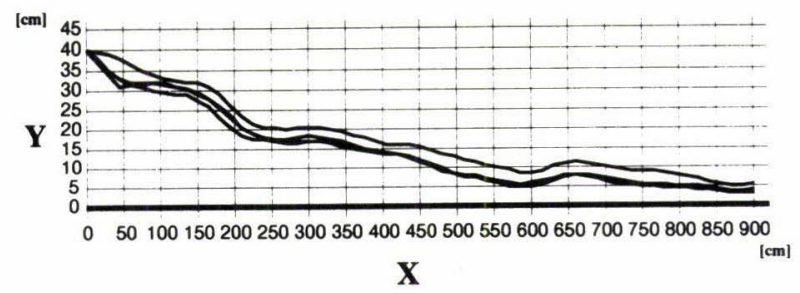

Fig.17 Trajectries of autonomous navigation (2)

現れていると思われるが，その影響は $5[\mathrm{~cm}]$ 程度と見られ特に 問題にはならない大きさであった．

\subsection{3 初期位置のずれへの対応}

自律走行時のスタート位置をずらした場合の目標軌道までの 追従実験の結果を Fig. 17 に示す、スタート位置を $40[\mathrm{~cm}]$ 横 にずらして 4 回の自律走行を行った. 本手法の制御は前に述べ たように単純なものであるが，進むに従って目標軌道に近づき， 扔よそ $7[\mathrm{~m}]$ 進んだ位置で誤差 $10[\mathrm{~cm}]$ 以内に入っている。ま たスタート地点での姿勢のずれを（マッチングが失敗しない範 囲で）与えても自律走行には特に影響しなかった。このように， 初期位置の誤差にも十分対応できているという結果が得られた。

\section{6. おわりに}

本稿では, 視野画像列経路表現という, 縮小した進行方向の 視野画像列を記憶した経路モデルを提案し，屋内の実環境に対 応できる移動ロボットの誘導に利用した，本手法では，記録走 行時に視野画像を列として記憶することで, 自律走行時の自己 位置の同定と進行方向の決定，障害物の検出という環境認識を 相関演算に基づくマッチングにより行うことができる．また実
時間の自律走行制御と容易な経路教示を実現し, 実際に移動口 ボットを用いて行った走行実験により，その有効性を確認した。 この手法は，

・記録走行時と自律走行時でシーンの見え方（明るさ，物の 配置など）が大きく変化しない

・カメラの視野に, マッチングに用いることができるある程

度近くまでの走行環境（床, 壁など）が映っている という条件を満たす環境に対応することができる．多くの既存 の建物内の環境はこの条件を満たしているため, 本手法が適用 できると考えられる．

今後は, 位置姿勢を同時に認識できるマッチング手法, およ びカラー画像, エッジ画像など明るさの変化に強い特徴量を用 いたよりロバストなマッチング手法を開発し, 本手法の適用範 囲を広げていきたい.

\section{参 考 文 献}

[1] D. A. Pomerleau: "ALVINN: An Autonomous Land Vehicle in a Neural Network," Technical Report CMU-CS-89-107, CMU, 1989.

[2] M. Meng and A. C. Kak: "NEURO-NAV: A Neural Network Based Architecture For Vision-Guided Mobile Robot Navigation Using Non-Metrical Models of the Environment," In Proc. of Int'l Symp. on Robotics Research (ISIR'93), pp.750-757, 1993.

[3] C. Furlanello, B. Crespi and L. Stringa: "A memory based approach to navigation," Biological Cybernetics, vol.69, pp.385-393, 1993.

[4] J. Y. Zheng and S. Tsuji: "Panoramic Representation for Route Recognition by Mobile Robot," International Journal of Computer Vision, vol.9, no.1, pp.55-76, 1992.

[5] 前田武志, 石黒浩, 辻三郎：“全方位画像を用いた記憶に基づく未知 環境の探索”, 電子情報通信学会技術研究報告, PRU92-10, pp.73-80, 1995.

[6]黒須, 大矢, 油田: “画像による移動ロポットのポジショニングと誘導”, ロボティクス・メカトロニクス講演会 '94 講演論文集, pp.1178-1183, 1994.

７７松本勉, 油田信一：“経路地図に従った移動ロボットの自律走行シス テム”, 日本ロボット学会誌, vol.5, no.5, pp.351-359, 1987.

[ 8 ] I. Horswill. Polly: "A Vision-Based Artificial Agent," In Proc. of Int'l Conf. on AAAI '93, pp.824-829, 1993

[9]井上博允, 稲葉雅幸, 森武俊, 立川哲也：“局所相関演算に基づく実 時間ピジョンシステムの開発”, 日本ロボット学会誌, vol.13, no.1, pp.134-140, 1995.

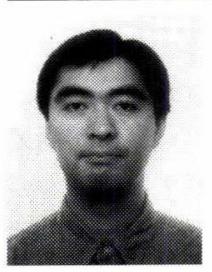

松本吉央 (Yoshio Matsumoto)

1970 年 8 月 21 日生. 1993 年東京大学工学部卒業. 1995 年同大学院修士課程修了. 現在同博士課程在 学中.ロボットビジョンの研究に従事. 電子情報通 信学会, 人工知能学会, IEEEの学生会員.

(日本ロボット学会学生会員)

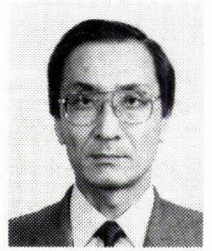

井上博允 (Hirochika Inoue)

1942 年生. 1965 年東京大学工学部卒業. 1970 年同 大学院博士課程修了. 工学博士. 同年電子技術総合 研究所入所. 知能ロボットの研究開発に従事. 1977 年東京大学工学部機械工学科助教授. 1984 年教授. 現在, 機械情報工学科教授. ロボット全般, 人工知 能, 情報システム工学の研究と教育に従事.

（日本ロボット学会正会員）

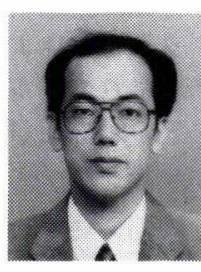

稲葉雅幸 (Masayuki Inaba)

1958 年 5 月 23 日生. 1981 年 3 月東京大学工学部 卒業. 1986 年 3 月同大学大学院工学系研究科情報 工学専門課程修了. 工学博士. 同年 4 月東京大学講 師. 1989 年同助教授. 現在, 機械情報工学科勤務. 日本機械学会, 情報処理学会, 計測自動制御学会, 人工知能学会各会員.（日本ロボット学会正会員） 